\title{
Nonpreference of the Lace Bug Leptopharsa heveae Drake \& Poor (Heteroptera: Tingidae) for Rubber Tree clones
}

\author{
Fernando M. Lara ${ }^{1}$ and Marcel R. Tanzini ${ }^{1}$ \\ ${ }^{1}$ Departamento de Entomologia e Nematologia, FCAV/UNESP, Campus de Jaboticabal, \\ Rodovia Carlos Tonanni, km 5, 14870-000, Jaboticabal, SP.
}

An. Soc. Entomol. Brasil 26(3): 429-434 (1997)

\begin{abstract}
Não-Preferência do Percevejo-de-Renda Leptopharsa heveae Drake \& Poor
(Heteroptera: Tingidae) por Clones de Seringueira
\end{abstract}

\begin{abstract}
RESUMO - Objetivou-se verificar a resistência de clones de seringueira (Hevea brasiliensis) a Leptopharsa heveae Drake \& Poor (Heteroptera: Tingidae) em Itiquira, MT, de 1994 a 1995, comparando-se os clones: AVROS 2037, Fx 4037, GT 1, HARBEL, IAC 207, IAN 4493, IAN 717, IAN 873, RO 38 e RO 46. Foram realizados ensaios de preferência para oviposição e alimentação, com e sem chance de escolha, em condições de campo e laboratório. Efetuaram-se as avaliações através de: notas atribuídas aos sintomas causados pelo inseto, número de excrementos, número de ovos/fêmea/folíolo, percentagens de mortalidade e número de insetos/folíolo. Pode-se concluir que os clones Fx 4037, RO 38 e RO 46 revelaram-se resistentes, apresentando resistência do tipo não-preferência para alimentação e oviposição, enquanto GT 1 e IAN 873 foram os mais suscetíveis.
\end{abstract}

PALAVRAS-CHAVE: Insecta, Hemiptera, Hevea brasiliensis, resistência de plantas, antixenose.

\begin{abstract}
To determine the resistance of rubber tree clones (Hevea brasiliensis) to Leptopharsa heveae Drake and Poor (Heteroptera: Tingidae) a trial was held in Itiquira, MT, in 1994/95 by comparing the following clones: AVROS 2037, Fx 4037, GT 1, HARBEL, IAC 207, IAN 4493, IAN 717, IAN 873, RO 38, and RO 46. Free choice and no choice trials involving preference for oviposition and feeding were carried out under field and laboratory conditions. The symptoms caused by the insects, number of excrements, number of eggs/female/leaflet, mortality rate, and number of insects/leaflet were scored. The results showed that clones Fx 4037, RO 38 and RO 46 were resistant by nonpreference for feeding and oviposition, whereas GT and IAN 873 were the most susceptible.
\end{abstract}

KEY WORDS: Insecta, Hemiptera, Hevea brasiliensis, host plant resistance, antixenosis.

The lace bug Leptopharsa heveae Drake and Poor (Hemiptera: Tingidae) was first described by Drake \& Poor (1935) as one of the insects collected from rubber tree (Hevea brasiliensis) leaves in the Tapajo's River region, Boa Vista, Brazil. Kuffner (1986) con- 
sidered the insect to be a pest in the State of Mato Grosso, in São José do Rio Claro region. Batista Filho et al. (1995) detected the insect in São Paulo State, in Buritama County, on rubber clones PR 261 and GT 1.

The habit of both nymphs and adults of $L$. heveae is to remain on the lower surface of young and adult rubber tree leaves where they suck the sap and destroy the parenchyma; chlorophyll function of the tree is affected and lesions are produce that favor the attack of microorganisms (Carrera 1973). Comparing rubber trees infested and not infested with $L$. heveae, Moreira (1985) noted that infestation caused a $27.7 \%$ reduction in growth and a $43.5 \%$ reduction in the diameter of the tree.

Several methods have been used for the control of tingids, such as injections of insecticide into the stem of Platanus for protection against Corythuca ciliata (Say) (Mauri 1989), or systemic application through the roots in palm trees (Elaeis guineensis) for the control of Leptopharsa gibbicarina (Froeschner) using monocrotophos and dicrotophos (Reyes et al. 1988). Treatment of azaleas (Rhododendron) with Safer Soap (a product containing potassium salts and many fatty acids) and $0.125 \%$ acefate (Orthene) for the control of Stephanitis pyrioides (Scott) provided a control of 80 and 100\%, respectively, (Gill 1988, Gill \& Raupp 1989). The use of Sporotrix insectorum Hoogs \& Evans isolated from $L$. heveae showed $73 \%$ effectiveness in the laboratory and $43 \%$ effectiveness in the field against L. gibbicarina (Giraldo 1993). In view of the difficulty in controlling the pests of rubber trees due to their height, alternative methods have been sought, among them the use of resistant varieties. This represents an excellent perspective because resistant varieties reduce insect populations levels, do not interfere with the ecosystem, have cumulative and persistent effects, do not involve increased production costs and do not require specific knowledge by farmers (Lara 1991).

The objective of this study is to test the resistance of rubber tree clones to L. heveae.

\section{Material and Methods}

The study was conducted using different rubber tree clones on the Plantações E. Michelin Farm, in Itiquira County, MT, during 1994/95. Cuttings were grafted onto clone GT 1; this clone was seeded plastic bags containing red yellow latossol fertilized with 0 30-15 NPK (16 g/bag). In May 1994, the clones AVROS 2037, Fx 4037, GT 1, HARBEL, IAN 4493, IAN 717, IAN 873, PB 235, RO 35 and RO 46 were grafted.

Field Trials. For the determination of feeding and oviposition preference, a free choice trial was set up using cages $(2 \times 1.8 \times 1 \mathrm{~m})$ covered with white nylon netting into which ca. 1000 adults were released. After 1, 2 and 7 days, numbers of insects and eggs/leaflet were counted and the symptoms caused by the insects on the leaflets were scored according to the following scale: $1<25 \%$ symptoms; $2=26$ to $50 \% ; 3=51$ to $75 \%$, and 4 $>75 \%$. The mean temperature and $\mathrm{RH}$ during the trial were $20.6^{\circ} \mathrm{C}$ and $73 \%$, respectively. The experimental design consisted of randomized blocks with five replications (cages), and the data were transformed to square root of $(x)$.

Another trial (no choice) for oviposition preference was set up using red-eyed adult insects (teneral adults) collected from the clone PB 235 and maintained on Petri dishes throughout the pre-oviposition period. One pair of insects was maintained on a leaf by 72 $\mathrm{h}$ using a minicage (Lara et al. 1979). The infested leaflets were removed and taken to the laboratory to count the number of eggs/ female. The data were transformed to square root of $(x+0.5)$ and analysed in a randomized block design with 30 replications (minicages).

Laboratory Trials. No choice feeding and oviposition preference trials were carried out on Petri dishes lined with moistened filter paper on which a leaflet from clones Fx 4037, GT 1, IAN 717 and RO 46 and 10 adult pairs were placed. This stage of the experiment lasted 7 days. The design was completely 
randomized with six replications and the data were duly transformed for statistical analysis by the $\mathrm{F}$ test. The means were compared by the Tukey test $(\mathrm{P} \leq 0.05)$.

\section{Results and Discussion}

Field Trials. Significant differences in the time needed to determine differences betwen the clones were detected seven days after infestation, with the insects showing higher preference for clone IAN 873 (68.5 adults/plant), lower preference for clones IAN 4493 (2.6 adults/plant) and IAN 717 (9.8 adults/plant), and intermediate preference for RO 38 and Fx 4037 (Table 1).
GT 1 were the most preferred for feeding (score > 2.0), and RO 38 and Fx 4037 were the least preferred (score < 1.0) (Fig. 1); again this suggests that the clones of Brazilian origin are more resistant. In general, the clones IAN 873 and GT 1 were the most preferred in both feeding and oviposition, whereas RO 38 and Fx 4037 revealed resistance of the nonpreference type. These results support previous data, indicating that the most attractive clone, IAN 873, was also the most preferred for feeding and oviposition.

Oviposition was the highest in clone GT 1 (7.1 eggs/leaflet), followed by IAN 873 (5.2 eggs/leaflet), and the insects had no preference for clones Fx 4037, RO 38, HARBEL

Table 1. Mean number $( \pm \mathrm{SE})$ of Leptopharsa heveae adults per rubber tree clones in a free choice field trial, Itiquira, MT, $1995 .^{1}$

\begin{tabular}{lrccc}
\hline & \multicolumn{5}{c}{ Days after infestation } \\
\cline { 2 - 5 } Clones & \multicolumn{5}{c}{2} & 2 & 7 \\
\hline IAN 873 & $124.3 \pm 13.7$ & $97.0 \pm 31.4$ & $68.5 \pm 19.1 \mathrm{a}$ \\
IAC 207 & $92.8 \pm 33.9$ & $58.8 \pm 27.6$ & $56.3 \pm 27.0 \mathrm{ab}$ \\
Fx 4037 & $165.0 \pm 66.6$ & $50.8 \pm 17.2$ & $30.5 \pm 10.1 \mathrm{ab}$ \\
RO 38 & $64.5 \pm 17.4$ & $50.3 \pm 17.1$ & $20.0 \pm 4.1 \mathrm{ab}$ \\
GT 1 & $65.8 \pm 22.6$ & $61.5 \pm 18.8$ & $16.0 \pm 4.7 \mathrm{ab}$ \\
AVROS & $76.5 \pm 5.0$ & $70.0 \pm 15.8$ & $14.8 \pm 2.7 \mathrm{ab}$ \\
IAN 717 & $50.0 \pm 14.8$ & $23.3 \pm 10.4$ & $9.8 \pm 7.3 \mathrm{~b}$ \\
IAN 4493 & $60.3 \pm 37.4$ & $56.6 \pm 41.5$ & $2.6 \pm 0.4 \mathrm{~b}$ \\
\hline F & $1.22 \mathrm{~ns}$ & $0.67 \mathrm{~ns}$ & $3.23^{*}$ \\
C.V.(\%) & 79.96 & 86.29 & 46.44 & \\
\hline
\end{tabular}

${ }^{1}$ Means followed by the same letter in each column do not differ using Tukey test $(\mathrm{P} \leq 0.05)$ (the data were duly transformed for analysis).

* Significant Tukey test $(\mathrm{P} \leq 0.05)$.

There was higher oviposition preference for clone IAN 873 (16.8 eggs/leaflet), followed by GT 1 (11.4 eggs/leaflet), and lack of preference for clones RO 38, Fx 4037 and IAC 207 (1.2 to 2.8 eggs/leaflet) (Fig. 1). This shows that clones from Asiatic ancestors were greater preferred for oviposition, whereas some clones of Brazilian origin proved to be more resistant.

Clones IAN 4493, IAN 873, AVROS and or RO46 (2.9 to 3.7 eggs/leaflet) (Fig. 2). These results confirm most of the data obtained in the free choice trial (Fig. 1), with nonpreference being observed mostly in clones of Brazilian origin.

Laboratory Trials. Clone GT 1 was the most preferred for oviposition (5.3 eggs/leaflet), whereas Fx 4037, RO 46 and IAN 717 were avoided, being chosen practically four times 


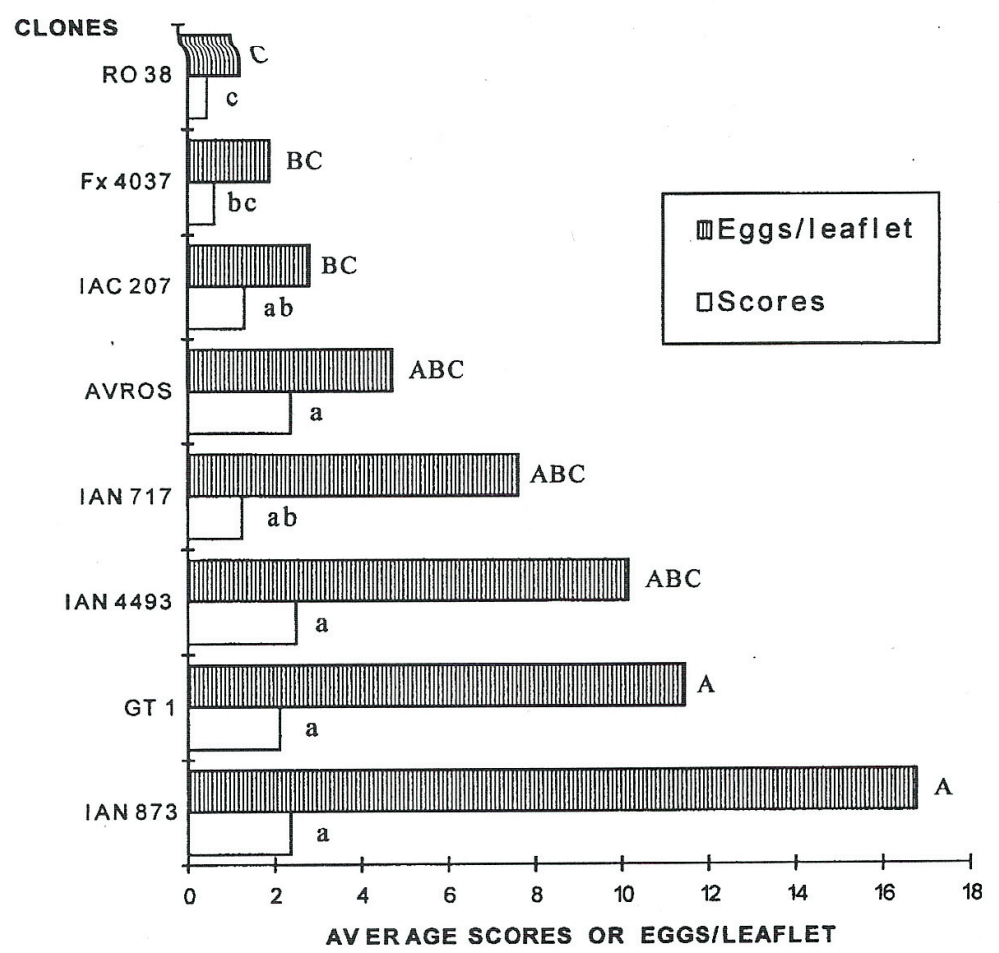

Figure 1. Mean scores attributed to the symptoms caused by Leptopharsa heveae in rubber tree clones and number of eggs/leaflet in a free choice field trial after seven days of infestation, Itiquira, MT, 1995. Columns with the same letter (capital letters for eggs/leaflet, small letters for scores) do not differ using Tukey test $(\mathrm{P} \leq 0.05)$.

less (1.5 to 1.8 eggs/leaflet) (Table 2). The scoring of symptoms and accumulated excrements/insect for the determination of feeding preference showed that clone Fx 4037 was the least preferred, followed by RO 46, whereas clone GT 1 was the most preferred.

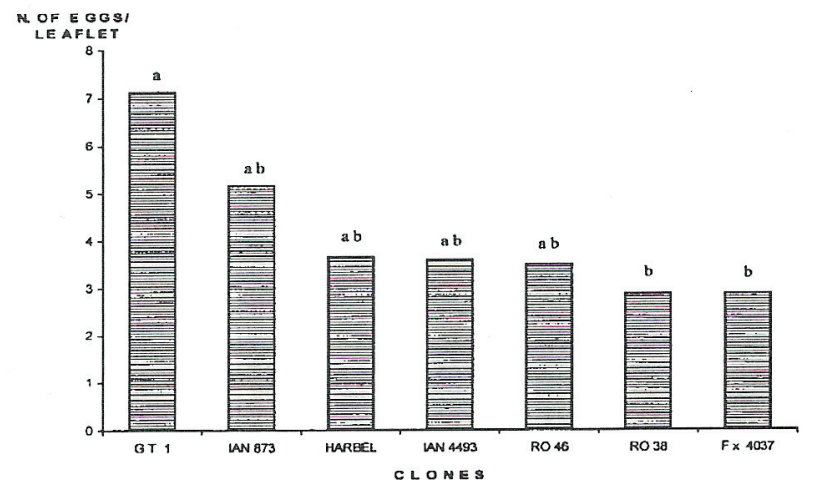

Figure 2. Mean number of Leptopharsa heveae eggs/female/leaflet of rubber tree clones after $72 \mathrm{~h}$ in a no choice field trial, Itiquira, MT, 1995. Columns with the same letter do not differ using Tukey test $(\mathrm{P} \leq 0.05)$. 
Table 2. Mean number of Leptopharsa heveae eggs/female/leaflet of rubber tree clones, scores/leaflet, number of excrements/insect and mortality rate of adults/plate in no choice laboratory assays ( \pm SE), Itiquira, MT, 1995 . $^{1}$

\begin{tabular}{lcccc}
\hline Clones & $\begin{array}{c}\text { eggs/female/ } \\
\text { leaflet }\end{array}$ & scores/leaflet & $\begin{array}{c}\text { excrements/ } \\
\text { insect }\end{array}$ & $\begin{array}{c}\text { mortality rate } \\
(\%)\end{array}$ \\
\hline GT 1 & $5.3 \pm 1.0 \mathrm{a}$ & $4.0 \pm 0.0 \mathrm{a}$ & $19.4 \pm 1.7 \mathrm{a}$ & $20.8 \pm 7.0 \mathrm{a}$ \\
IAN 717 & $1.8 \pm 0.5 \mathrm{~b}$ & $3.7 \pm 0.2 \mathrm{a}$ & $14.0 \pm 1.5 \mathrm{~b}$ & $41.7 \pm 4.2 \mathrm{a}$ \\
RO 46 & $1.6 \pm 0.3 \mathrm{~b}$ & $3.5 \pm 0.3 \mathrm{a}$ & $10.6 \pm 0.8 \mathrm{bc}$ & $29.2 \pm 4.4 \mathrm{a}$ \\
Fx 4037 & $1.5 \pm 0.3 \mathrm{~b}$ & $1.7 \pm 0.2 \mathrm{~b}$ & $8.8 \pm 0.9 \mathrm{c}$ & $37.5 \pm 5.9 \mathrm{a}$ \\
\hline F & $11.15^{*}$ & $20.97^{*}$ & $13.76^{*}$ & $3.02 \mathrm{n} . \mathrm{s}$. \\
C.V. $(\%)$ & 24.17 & 9.98 & 11.64 & 29.15 \\
\hline
\end{tabular}

${ }^{1}$ Means followed by the same letter in each column do not differ using Tukey test $(\mathrm{P} \leq 0.05)$ (the data were duly transformed for analysis).

* Significant Tukey test $(\mathrm{P} \leq 0.05)$.

No significant difference in adult mortality rate was observed among the studied clones. These data suggest that none of these four materials had an antibiotic effect on lace bug adults.

On the basis of the results obtained, it may be concluded that the most preferred clones by $L$. heveae, in both feeding and oviposition tests, were GT 1 and IAN 873. Clones FX 4037, RO 38 and RO 46 showed resistance of the nonpreference type for feeding and oviposition.

\section{Acknowledgments}

The authors wish to thank $\mathrm{CNPq}$ and CAPES for fellowships, to Plantações E. Michelin Farm for the materials and facilities provided and Dr. Richard C. Froescher, of the Smithsonian Institute, for the identification of the species.

\section{References Cited}

Batista $F^{o}$, A., L.G. Leite \& A.P., Silveira. 1995. Ocorrência da mosca-de-renda, Leptopharsa heveae, em Buritama, SP. Arq. Inst. Biol. 62: 81.

Carrera, M. 1973. Entomologia para você. 4a ed. São Paulo, Edart, 185p.

Drake, C.J. \& M.E., Poor. 1935. An undescribed rubber tingitid from Brazil (Hemiptera). Insetos do Brasil 25: 283284.

Gill, S.A. 1988. Insecticidal soap as an azalea lacebug control. J. Amer. Rhododendron Soc. 42: 103-104.

Gill, S.A. \& M. Raupp. 1989 Control of azalea lace bug using insecticidal soap and neem. J. Amer. Rhododendron Soc. 43: 216-217.

Giraldo, A.I.D.H.O. 1993. Sporotrix insectorum: biological control method of the lace bug Leptopharsa gibbicarina in oil palm culture in Latin America (Hemiptera: Tingidae). Bull. Soc. Entomol. France 98: 77-85.

Lara, F.M. 1991. Princípios de resistência de plantas a insetos. $2^{\mathrm{a}}$ ed., São Paulo, Icone Ed., 336p.

Lara, F.M., A. Coelho \& J. Mayor Jr. 1979. Resistência de variedades de couve a Brevicoryne brassicae (L., 1758). II. 
Antibiose. An. Soc. Entomol. Brasil 8: 217223.

Kuffner, J.R. 1986. Aspectos relevantes dos sistemas de explotação utilizados por pequenos produtores. In: Encontro Nac. Exp. Org. Seringais de Cultivo, 1. Brasília, SUDHEVEA, p. 67-71.

Mauri, G. 1989. Control trial against the american plane tiger (Corythuca ciliata) by injection of the trees. Rev. Hort. Suisse 62: 165-170.
Moreira, I.P.S. 1985. A Leptopharsa heveae (Drake \& Poor) e seus danos às mudas de Hevea brasiliensis (Muell.). Tese de mestrado, UFPR, Curitiba, 48p.

Reyes, A.R., M.A. Cruz \& P. Genty. 1988. The root absorption technique for controlling oil palm pests. Oleagineux 43: 363-370.

Received 10/X/96. Accepted 21/VIII/97. 